\title{
Asthma in Latin America
}

\section{Erick Forno, ${ }^{1}$ Mudita Gogna, ${ }^{1}$ Alfonso Cepeda, ${ }^{2}$ Anahi Yañez, ${ }^{3}$ Dirceu Solé, ${ }^{4}$ Philip Cooper, ${ }^{5,6}$ Lydiana Avila, $^{7}$ Manuel Soto-Quiros, ${ }^{7}$ Jose A Castro-Rodriguez, ${ }^{8}$ Juan C Celedón ${ }^{1}$}

- Additional material is published online only. To view please visit the journal online (http://dx.doi.org/10.1136/ thoraxjnl-2015-207199).

For numbered affiliations see end of article.

\section{Correspondence to}

Dr Juan C Celedón, Division of Pediatric Pulmonary Medicine,

Allergy, and Immunology, Children's Hospital of Pittsburgh of UPMC, 4401 Penn Avenue, Suite 9130, Rangos Building, Pittsburgh, PA 15224, USA juan.celedon@chp.edu

Received 19 April 2015 Revised 30 May 2015 Accepted 2 June 2015 Published Online First 23 June 2015

\section{CrossMark}

To cite: Forno $\mathrm{E}$, Gogna $\mathrm{M}$, Cepeda A, et al. Thorax 2015;70:898-905.

\section{ABSTRACT}

Consistent with the diversity of Latin America, there is profound variability in asthma burden among and within countries in this region. Regional variation in asthma prevalence is likely multifactorial and due to genetics, perinatal exposures, diet, obesity, tobacco use, indoor and outdoor pollutants, psychosocial stress and microbial or parasitic infections. Similarly, non-uniform progress in asthma management leads to regional variability in disease morbidity. Future studies of distinct asthma phenotypes should follow-up well-characterised Latin American subgroups and examine risk factors that are unique or common in Latin America (eg, stress and violence, parasitic infections and use of biomass fuels for cooking). Because most Latin American countries share the same barriers to asthma management, concerted and multifaceted public health and research efforts are needed, including approaches to curtail tobacco use, campaigns to improve asthma treatment, broadening access to care and clinical trials of non-pharmacological interventions (eg, replacing biomass fuels with gas or electric stoves).

\section{INTRODUCTION}

According to the WHO, 235 million people worldwide have asthma,${ }^{1}$ with the number likely to be higher due to underdiagnosis. The International Study of Asthma and Allergies in Childhood (ISAAC) and other studies have shown a marked increase in the prevalence of asthma worldwide over the last few decades. Whereas there has been a recent plateau in this trend in industrialised nations, a rising trend continues in many nonindustrialised countries. ${ }^{2} 3$

In the USA, the prevalence of current asthma is $\sim 8 \%$ in adults and $9.3 \%$ in children. ${ }^{4}$ In contrast, over half of Latin American countries report a prevalence of childhood asthma $>15 \% .{ }^{5}$ Moreover, most deaths from asthma occur in lowincome and middle-income countries such as those in Latin America.

We provide an update on literature on asthma in Latin America published since a previous review 6 years ago, ${ }^{6}$ or not covered in a more recent review that excluded data from Brazil and certain topics such as perinatal and allergen exposures. Increased understanding of asthma in this region should lead to better prevention, diagnosis and treatment of this disease in Latin Americans.

\section{SEARCH STRATEGY}

We searched PubMed and SciELO for articles containing the terms "asthma", "wheeze", or "airway hyperreactivity" and either "Latin America" or the name of any Latin American country. We selected the most relevant articles from the last five years, with exceptions made for topics with few research articles. We used original complete texts in English, Spanish or Portuguese when available, or abstracts otherwise.

\section{ASTHMA PREVALENCE, MORBIDITY AND MORTALITY}

Latin America is a geographically, politically and economically diverse region comprising 20 countries whose languages are primarily Spanish and Portuguese (table 1). It covers $13 \%$ of the earth's land surface area, and stretches from Mexico, through the Caribbean and Central America, to Argentina. Including Puerto Rico (a US territory with Hispanic roots), Latin America has 600 million people. If all countries within the Americas where a Romance language is predominantly spoken (eg, French or Creole) were included, this population would approach 603 million people.

ISAAC provided the first estimates of the prevalence of asthma or asthma symptoms in the region using standardised questionnaires. The prevalence of physician-diagnosed asthma in ISAAC and other studies varies widely among Latin American countries (table 1). In children ages 13-14 years, phase III of ISAAC showed that the prevalence of 'current wheeze' ranged from $8.7 \%$ in Mexico to $30.8 \%$ in El Salvador, and that of 'ever asthma' ranged from $6.9 \%$ in Mexico to $33.1 \%$ in Peru (figure 1)..$^{5}$ Asthma burden also varied within countries: among 17 centres in Brazil, the prevalence of 'ever asthma' ranged from $7.3 \%$ (Nova Iguaçu) to $21.2 \%$ (Porto Alegre). As expected in a region with limited resources, there may be significant underdiagnosis. A study in Havana, Cuba, reported that up to $~ 9 \%$ of children younger than 15 years may have undiagnosed asthma. ${ }^{10}$

Few studies have reported asthma prevalence among Latin American adults. Whereas a nationwide Colombian study estimated that $6.3 \%{ }^{11}$ of adults have physician-diagnosed asthma, a Mexican study estimated that $5 \%$ of adults have physiciandiagnosed asthma. ${ }^{12}$

Morbidity and mortality from asthma also vary among and within Latin American countries (table 1). While a 9-year Brazilian study found a slight increase (from $4.5 \%$ to $4.7 \%$ ) in the prevalence of severe asthma among adolescents, ${ }^{13}$ an ecological study using data from Brazilian children and adolescents showed a slow but steady decrement in asthma mortality from 1980 to 2007 , with the most marked decrement among children younger than 5 years. ${ }^{14}$ 
Table 1 Current wheeze and asthma in children ages 13-14 years and asthma mortality in Latin American countries 5 7-9

\begin{tabular}{|c|c|c|c|}
\hline Country & $\begin{array}{l}\text { Population } \\
\text { (millions) }\end{array}$ & $\begin{array}{l}\text { Asthma diagnosis, } \\
\text { ever (\%) }\end{array}$ & $\begin{array}{l}\text { Asthma } \\
\text { mortality* }\end{array}$ \\
\hline Argentina & 41505209 & 9.3 & 14.7 \\
\hline Bolivia & 10489027 & 12.3 & \\
\hline Brazil & 202332357 & 13.3 & \\
\hline Chile & 17198908 & 15.1 & 23.5 \\
\hline Colombia & 47258555 & 14.2 & 19.6 \\
\hline Costa Rica & 4667048 & 23.2 & 18.0 \\
\hline Cuba & 11112443 & 30.9 & \\
\hline $\begin{array}{l}\text { Dominican } \\
\text { Republict }\end{array}$ & 9982315 & 14.2 & \\
\hline Ecuador & 15609215 & 10.9 & \\
\hline El Salvador & 6371795 & 24.0 & \\
\hline Guatemala & 15439192 & 2.6 & 33.0 \\
\hline Haiti & 10333866 & & \\
\hline Honduras & 8566536 & 18.3 & \\
\hline Mexico & 114407027 & 6.9 & 27.1 \\
\hline Nicaragua & 6002266 & 15.2 & 41.8 \\
\hline Panama & 3633434 & 20.5 & \\
\hline Paraguay & 6824642 & 12.8 & \\
\hline Peru & 30475572 & 33.1 & 25.8 \\
\hline Puerto Rico $\ddagger$ & 3628043 & 21.8 & 33.0 \\
\hline Uruguay & 3310730 & 17.0 & \\
\hline Venezuela & 30704465 & 29.7 & \\
\hline $\begin{array}{l}\text { Total population/ } \\
\text { mean }\end{array}$ & 599852642 & 18.0 & 26.3 \\
\hline
\end{tabular}

Consistent with findings elsewhere, urban residence is associated with higher risk of asthma in Latin America. Using the ISAAC video questionnaire in Oropeza (Bolivia), Solis Soto et $a l^{15}$ showed that children in urban areas had nearly twofold higher odds of asthma than those in rural areas. Similar findings were obtained in an ecological study of 59 transitional communities in Ecuador, where urbanisation was associated with higher prevalence of asthma $(\mathrm{r}=0.36, \mathrm{p}=0.006){ }^{16}$ Although this rural-urban gradient in asthma could be due to differences in microbial or parasitic infections (the 'hygiene hypothesis'), other factors (eg, stress, pollution) may play a role.

\section{ANCESTRY, GENETICS AND EPIGENETICS}

The wide variation in asthma prevalence and morbidity between two Hispanic subgroups in the USA (Mexican Americans and Puerto Ricans) has been described as the 'Hispanic Paradox', ${ }^{7}$ a term initially coined for overall and cardiovascular mortality. ${ }^{17}$ This paradox naturally extends to Latin America (where asthma burden is lowest in Mexico) and likely results from interactions between nature and nurture.

Latin Americans are often racially admixed, with heterogeneous proportions of European, Native American and African ancestry. Differences in racial ancestry could partly explain the 'Hispanic Paradox': whereas African ancestry has been associated with lower lung function in Puerto Rican children with and without asthma, ${ }^{18}$ Native American ancestry has been associated with higher lung function in Costa Rican adults with and without COPD. ${ }^{19}$ Moreover, a recent admixture study found a positive association between Native American subcontinental ancestry and lung function in Mexicans. ${ }^{20}$ Whether ancestral effects on lung function are due to correlated allelic variants or environmental exposures is unclear.

Relatively few studies have examined asthma genetics in Latin Americans, and even fewer have attempted to identify de novo susceptibility genes for asthma in this population. Most studies in Latin Americans include one of a few subgroups (Mexicans, Puerto Ricans, Costa Ricans, Colombians or Brazilians) and focus on replicating candidate genes identified in other populations (e.g. transforming growth factor beta 1 (TFGB1), ${ }^{21}$ the 17 q21 locus, ${ }^{22}{ }^{23}$ interleukin 13 (IL13), ${ }^{24}$ gluthatione S-transferase mu 1 (GSTM1), ${ }^{25}$ matrix metallopeptidase 9 $(M M P 9)^{26}$ and the beta2-adrenergic receptor (ADRB2)). ${ }^{27} 28 \mathrm{On}$ the other hand, two susceptibility genes for asthma-related phenotypes first identified in Latin Americans include thymic stromal lymphopoietin $(T S L P)^{29}$ and matrix metalloproteinase 12 (MMP12). ${ }^{30}$ In both cases, findings in Costa Ricans have been replicated in non-Latin Americans.

Few genome-wide association studies (GWAS) of asthma have included subjects of Latin American descent, often used for replication purposes. Findings from a meta-analysis of GWAS of asthma in North American populations were replicated for four genes in 'Latinos': TSLP, interleukin 33 (IL33), interleukin 1 receptor-like 1 (IL1RL1) and the $17 \mathrm{q} 21$ locus. ${ }^{31}$ Unfortunately, the 'Latino' group was a mix of Costa Ricans, Hondurans, Puerto Ricans and US Hispanics, precluding conclusions about specific subgroups. Other GWAS of asthma or related phenotypes conducted in Latin Americans ${ }^{32}$ or including Latin Americans $^{23} \quad 33 \quad 34$ have not yielded genome-wide significant associations or failed to consistently replicate their findings in other populations, which may be explained by inadequate statistical power or false positive results. To date, no ethnic-specific asthma susceptibility gene has been identified in Latin American subgroups.

Few candidate-gene studies have examined gene-byenvironment interactions, and only one study has examined asthma epigenetics in Latin America. ${ }^{35-38}$ Two studies replicated interactions between candidate genes (IL10 and TGFB1) and dust mite allergen in Costa Ricans in an independent cohort, and another demonstrated that violence exposure is associated with DNA methylation of the gene for the pituitary adenylate cyclase-activating polypeptide type 1 receptor (ADCYAP1R1), which is in turn associated with asthma in Puerto Rican children.

In summary, current evidence suggests that whereas most risk alleles for asthma are 'cosmopolitan' (affecting all ethnic groups to various degrees), some are 'race/ethnic-specific' (affecting only or predominantly certain groups). ${ }^{31}$ Large-scale genetic and epigenetic studies are needed to assess the relative contribution of risk alleles to asthma in Latin American subgroups, acting alone or interacting with the environment. Studies of this magnitude are challenging, but ISAAC $^{3}$ and the Proyecto Latino-Americano de Investigación en Obstrucción Pulmonar (PLATINO) study of COPD ${ }^{39}$ are successful models of collaborative studies in Latin America.

\section{EARLY-LIFE RISK FACTORS}

A cross-sectional study of 3003 infants in Brazil showed that risk factors for recurrent wheeze included daycare attendance, $\geq 6$ colds in the first year of life (adjusted OR $(\mathrm{aOR})=1.3,95 \%$ CI 1.2 to 1.4$)$ ), pets other than dogs during pregnancy $(\mathrm{aOR}=1.3,95 \% \mathrm{CI} 1.1$ to 1.5$)$ and mould in the home. In contrast, up-to-date immunisations $(\mathrm{aOR}=0.8,95 \% \mathrm{CI} 0.6$ to 1.0$)$ and a bathroom in the home were inversely associated with recurrent wheeze. ${ }^{40}$ Similar findings were obtained in a study of $>28000$ infants in Latin America (Brazil, Chile and Venezuela) 


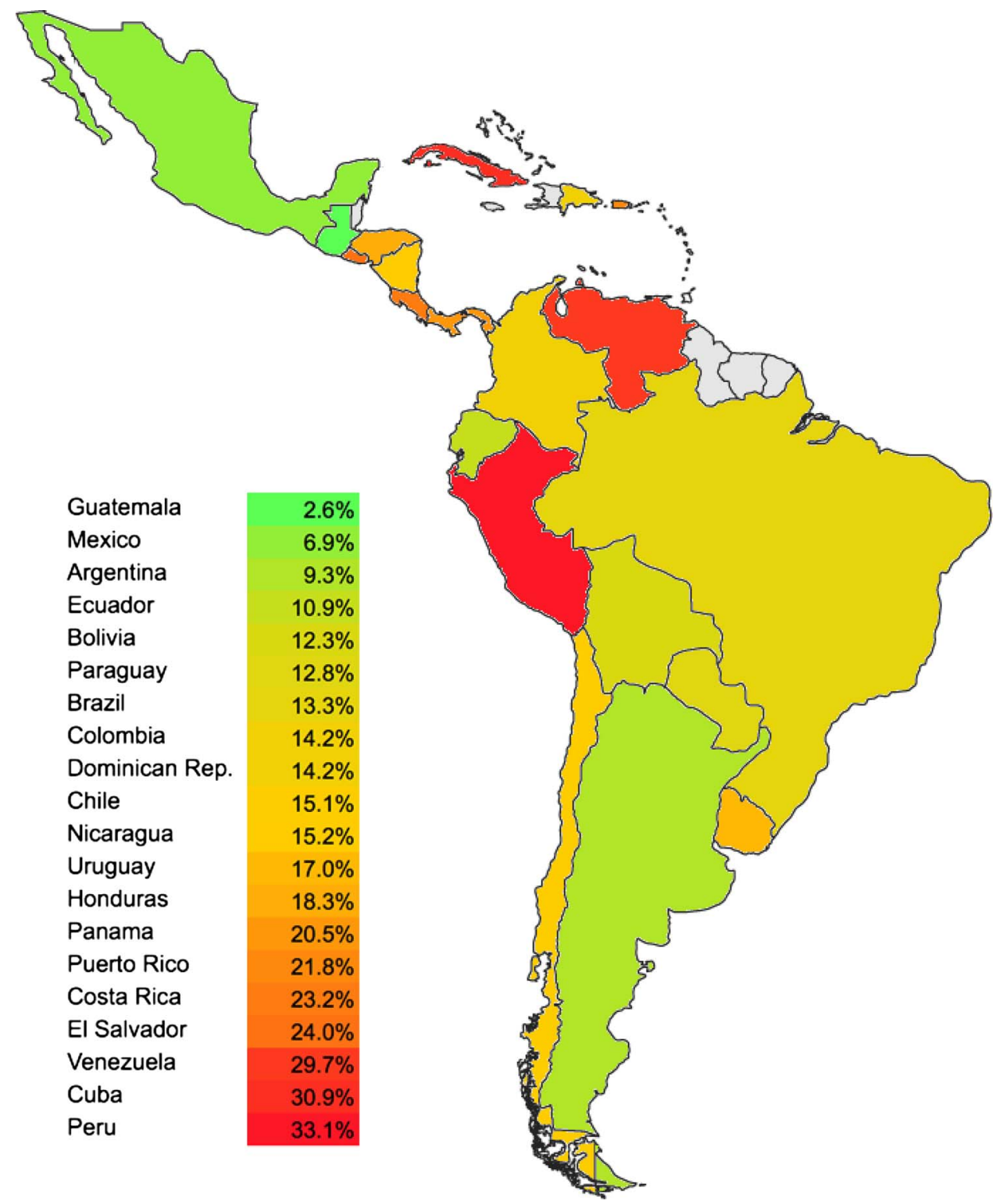

Figure 1 Prevalence of childhood asthma in Latin America. ${ }^{5-9}$ Prevalence in the Dominican Republic is based on adult asthma.

and Europe (Spain and the Netherlands). ${ }^{41}$ In that study, risk factors for recurrent wheeze in Latin America included a cold in the first trimester of life, daycare attendance and maternal smoking during pregnancy; factors associated with lower risk of recurrent wheeze included breast feeding $>3$ months $(\mathrm{aOR}=0.8,95 \%$ CI 0.7 to 0.9$)$ and maternal education beyond high school ( $\mathrm{aOR}=0.8,95 \% \mathrm{CI} 0.7$ to 0.9 ). Similar findings for breast feeding were obtained in a recent cross-sectional study of Puerto Rican school-aged children, in whom breast feeding for $\leq 6$ months was associated with $30 \%$ lower odds of asthma (95\% CI 0.5 to 1.0$){ }^{42}$

Little is known about perinatal events and asthma in Latin America. Among 678 Puerto Rican children ages 6-14 years, ${ }^{43}$ prematurity was associated with nearly fivefold increased odds of asthma in atopic children (95\% CI 1.5 to 14.3 ). In contrast, there was no significant association in non-atopic children. Although findings from this cross-sectional study must be cautiously interpreted, they are consistent with a 'two-hit' hypothesis involving structural lung changes and atopy in the development of asthma in premature children.
In summary, current findings suggest that early-life risk or protective factors for recurrent wheeze in Latin American infants are similar to those identified elsewhere. Birth cohort studies are needed to assess the relative contribution of these exposures and identify novel risk factors for asthma in Latin America.

\section{DIET AND OBESITY}

Vitamin D deficiency or insufficiency has been associated with asthma in Peruvian children and with severe asthma exacerbations in Costa Rican and Puerto Rican children. ${ }^{44-46}$ Other studies have focused on global diet instead of vitamins or nutrients, reporting that fast food ${ }^{47}$ or a 'Western' dietary pattern ${ }^{48}$ is associated with higher asthma risk in Mexico and Brazil, while higher fruit and vegetable intake or a 'Mediterranean' diet is associated with reduced airway inflammation and higher lung function in Mexican children. ${ }^{49}$

In one of few clinical trials of nutrients and asthma in Latin America, docosahexaenoic acid supplementation in the second and third trimesters of pregnancy led to lower risk ( $\mathrm{aOR}=0.76$, 
$95 \%$ CI 0.58 to 1.0 ) and shorter duration of colds, cough and wheezing in Mexican infants at age 1 month, but not at 3 or 6 months. ${ }^{50}$ Further clinical trials of dietary interventions on asthma are needed in this region.

Overweight and obesity affect $\sim 16-36 \%$ of children in Latin America. ${ }^{51}$ Consistent with findings elsewhere, overweight or obesity has been associated with asthma (aORs $\sim 1.3-1.8)^{52} 53$ or asthma severity ${ }^{53} 54$ in Latin Americans. However, the mechanisms or modifiers (eg, age, gender and type of obesity (general vs central)) of the putative effects of obesity on asthma remain unclear. Obesity has been associated with a pro-inflammatory state in Mexicans, ${ }^{55}$ in whom 'obese asthma' has been linked to metabolic syndrome. ${ }^{56}$ There has been no adequate clinical trial of weight loss and asthma in Latin America.

\section{PSYCHOSOCIAL STRESS}

Intimate partner violence, which is frequent in Latin America, is associated with adverse pregnancy outcomes. ${ }^{57}$ Similarly, perinatal depression can affect up to $20 \%$ of mothers. ${ }^{58}$ Consistent with findings outside of Latin America, stress, depression and mental illness in the mother or father have been linked to childhood asthma in Brazil ${ }^{59}{ }^{60}$ and Puerto Rico. ${ }^{61}$

We reported that physical or sexual abuse is associated with asthma morbidity in school-aged Puerto Ricans. ${ }^{62}$ Exposure to violence has been associated with asthma or asthma symptoms among children in Brazil (aOR for symptoms $=1.9$, 95\% CI 1.1 to 3.4$)^{63}$ and Puerto Rico, ${ }^{38}$ and preliminary evidence suggests that this may be partly explained by ADCYAP1R 1 methylation. ${ }^{38}$ More recently, we showed that child stress may affect asthma morbidity by reducing bronchodilator response (BDR), and that an $A D C Y A P 1 R 1$ single-nucleotide polymorphism is associated with both reduced $A D R B 2$ expression and reduced BDR. ${ }^{64}$ To date, there has been no study of stress-reducing interventions on asthma in Latin America.

\section{INFECTIONS AND PARASITE INFESTATION}

Findings from Latin America suggest that chronic and heavy parasitic infection reduce the risk of atopy, while intermittent or light parasitic infection may increase such risk. ${ }^{65}$ '66 Moreover, timing of infection may be key, as heavy infection with Trichuris trichiura and Ascaris lumbricoides during infancy has been shown to reduce the risk of atopy at school age among Brazilians $(\mathrm{aOR}=0.40,95 \% \mathrm{CI} 0.17$ to 0.94$){ }^{67}$

A. lumbricoides sensitisation (without or with concurrent infection) has been associated with asthma, wheeze or greater asthma severity ${ }^{68-70}$ among children in Costa Rica, Brazil and Ecuador (aOR for asthma 2.24 to $2.60,95 \%$ CI 1.33 to 4.38 ; aOR for asthma hospitalisations $=3.08$, 95\% CI 1.23 to 7.68 ). Whether this finding is explained by intermittent/light helminthiasis $^{71} 72$ (affecting the immune system or the lung through larvae migration) or other mechanisms (eg, a genetic predisposition to poly-sensitisation or cross-reactivity with other allergens) is unclear.

Conflicting results illustrate the complex relation between parasitic infections and asthma in Latin America. Whereas some studies have shown that helminthiasis or toxocariasis increase the risk of non-atopic wheezing, ${ }^{73}$ airway hyper-reactivity, ${ }^{74}$ atopic asthma ${ }^{70}$ and severe asthma ${ }^{75}$ in Brazilian and Argentinean children, studies in Ecuadorean children have shown that active parasitic infections might reduce the risk of atopic wheeze ${ }^{68} 76$ or that treatment with anti-helminthics does not affect asthma symptoms. ${ }^{77}$ Longitudinal studies are needed to better delineate the roles of host and type of infection on asthma at different ages (as risk factors for early-childhood wheeze may protect against asthma later in life).

Consistent with findings elsewhere, early or frequent nonparasitic respiratory infections (eg, viral) have been associated with wheeze or asthma in Brazilian children. ${ }^{78-80}$ However, no study has used molecular-based techniques to assess the longterm impact of these infections on asthma in Latin Americans.

\section{ALLERGENS AND POLLUTANTS}

Exposure and sensitisation to dust mite allergens are common and associated with asthma in cross-sectional studies in Latin America. ${ }^{81} 82$ More recently, several studies have examined allergens other than dust mite and asthma in this region. Indoor exposure to fungi or mould has been associated with asthma symptoms, airway hyper-responsiveness and severe asthma exacerbations in Colombian, Costa Rican and Puerto Rican children. ${ }^{82-84}$ Among school-aged Puerto Ricans with and without asthma, mouse allergen was associated with higher $\mathrm{FEV}_{1}$ and lower risk of atopy $(\mathrm{aOR}=0.8,95 \%$ CI 0.6 to 0.9$)$ or allergic rhinitis $(\mathrm{aOR}=0.75,95 \% \mathrm{CI} 0.62$ to 0.92$) .{ }^{85} 86$ This finding is consistent with that of a North American study ${ }^{87}$ and may be due to the effects of anaerobic bacteria in murine faeces on immune responses.

Environmental tobacco smoke (ETS) and current smoking are risk factors for asthma morbidity. In a study from Argentina, $\sim 60 \%$ of the population was exposed to ETS in their homes and $\sim 90 \%$ at work. ${ }^{88}$ Active smoking is common among Latin American teenagers due to cultural factors, lack of regulation and poor law enforcement. Active smoking was associated with $\sim 83 \%$ increased odds of asthma in a study of Argentinean adolescents, who were more likely to be smokers when exposed to ETS at home. ${ }^{88}$ Further emphasising the detrimental effects of smoking, a study of 4738 Latin American adolescents in ISAAC showed that $\geq 27 \%$ of asthma symptoms were attributable to tobacco use. $^{89}$

Air pollution is a risk factor for asthma morbidity in urban Latin America. Exposure to traffic exhaust (particularly from diesel-fuelled motor vehicles) was associated with cough, wheezing and lower lung function among children with asthma in Mexico City. ${ }^{90}$ Similar findings for lung function were reported for $\mathrm{PM}_{10}$ and $\mathrm{NO}_{2}$ in Brazilian children. ${ }^{91}$ In Argentina, children living near the country's main oil refinery had a higher prevalence of asthma and asthma exacerbations, and lower lung function than those living in other regions. ${ }^{92}$

Recent findings suggest joint detrimental effects of vitamin D insufficiency and traffic-related air pollution on severe asthma exacerbations in Puerto Ricans. ${ }^{93}$ Compared to children who had vitamin D sufficiency and lived furthest from a major road, those who had vitamin D insufficiency and lived closest to a major road had nearly fivefold higher odds of $\geq 1$ severe asthma exacerbation in the previous year (95\% CI 2.1 to 10.7$)$. A study in Mexico City showed that children with low vitamin C levels and certain GSTM1 genotypes may be more susceptible to the negative effects of ozone exposure on lung function. ${ }^{37}$ These findings suggest that low levels of antioxidants such as vitamin D or C may lead to increased oxidative stress or, alternatively, more severe viral infections after exposure to pollutants.

Indoor pollution is a health hazard in rural Latin America: $\sim 27$ million people use biomass fuels as a source of energy in rural Mexico. In a 1-year interventional study in Mexican women, using a Patsari stove for cooking reduced cough by $\sim 23 \%$ and wheeze by $\sim 70 \%$, and decreased the rate of lung function decline. ${ }^{94} \mathrm{~A}$ global analysis of ISAAC (which included 
46 500 Latin American children) reported an association between open-fire cooking and asthma symptoms. ${ }^{95}$

\section{MANAGEMENT INTERVENTIONS AND ECONOMIC IMPACT}

Public health efforts have improved asthma management in some countries. An ecological study showed a marked decrement in hospitalisations and mortality from asthma in Costa Ricans from 1997-2000 to 2011, likely due to nationwide educational campaigns leading to greater prescription of inhaled corticosteroids (ICS). ${ }^{96}$ Similar findings were reported for Argentina between 1990 and $1999 .{ }^{97}$ Laws regulating public smoking may also have reduced hospitalisations for childhood asthma. ${ }^{98}$

As few as $40 \%$ of patients are compliant with long-term medications for asthma, ${ }^{99}$ and thus education is critical. In a Colombian study, lower educational status, older age and unemployment were associated with inadequate use of metereddose inhalers. ${ }^{100}$ In other studies in Brazil and Chile, education on self-management led to improved asthma control. ${ }^{101} 102$ Medication cost is another major treatment barrier. A few studies of cost-effectiveness in Latin America have shown superiority of beclomethasone over other ICS, as well as of salmeterol/fluticasone over montelukast, in children whose asthma is not well controlled on ICS. ${ }^{103} 104$

Among 2074 patients from 10 Latin American countries, asthma had a negative impact on daily activities: $\sim 46 \%$ of people with mild asthma and $\sim 72 \%$ of those with severe asthma reported $\geq 1$ unscheduled healthcare visit, representing up to $73.2 \%$ of annual asthma-related costs. ${ }^{105}$ Thus, monitoring disease control is key to asthma treatment. Sputum nitrite has been correlated with asthma morbidity in Peruvian children, ${ }^{106}$ and questionnaires used to assess disease control in the USA (childhood asthma control test for schoolchildren ${ }^{107}$ and Test for Respiratory and Asthma Control in Kids for preschoolers ${ }^{108}$ ) have been recently validated in Latin Americans.

Comprehensive approaches are critical for asthma control. The Programme for Control of Asthma and Allergic Rhinitis (ProAR), aimed at severe asthma in Salvador (Brazil), reported a $74 \%$ reduction in hospitalisations, as well as reductions in costs to the patient and healthcare system. ${ }^{109}$ Direct asthma-related costs for a participant's family were reduced from $24 \%$ to $2 \%$ of annual income. ${ }^{110}$ ProAR included specialised care, patient education and free medications (including ICS).

Little is known about the impact of comorbidities on asthma in Latin America. Although treating allergic rhinitis may reduce asthma morbidity, this disease is significantly underdiagnosed among children with asthma in Costa Rica ${ }^{111}$ and Puerto Rico. ${ }^{112}$ In the Puerto Rican study, physicians were shown to miss $>75 \%$ of cases of allergic rhinitis in children with asthma. ${ }^{112}$ Such underdiagnosis could be easily corrected by asking about symptoms and triggers of rhinitis and measuring dust mite-specific IgE or total IgE. ${ }^{112}$

In summary, multipronged approaches to asthma management are needed. Such strategies must include adequate access to medications, patient education and monitoring asthma control.

\section{SUMMARY AND FUTURE DIRECTIONS}

Asthma is a syndrome comprising distinct phenotypes (eg, atopic vs non-atopic asthma, 'obese asthma') and diverse risk factors (see online supplementary table for a summary of the most relevant articles). While some causes of these phenotypes may overlap, others may be unique to a phenotype. Given the size and diversity of Latin America, one expects to encounter variability in the relative importance of each asthma phenotype and its contributing risk factors (figure 2). Atopic asthma

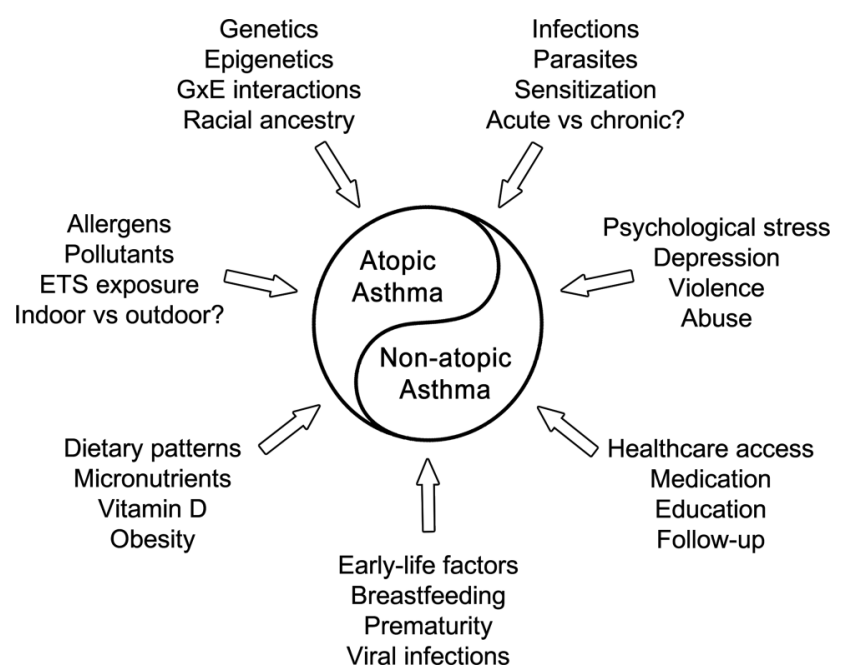

Figure 2 Risk factors for asthma in Latin America. ETS, environmental tobacco smoke; GxE, gene-by-environment.

predominates in countries such as Costa Rica or Puerto Rico, ${ }^{69} 84$ while non-atopic asthma prevails in nations such as Ecuador or Brazil (particularly in rural or impoverished areas). ${ }^{113} 114$ However, over-reporting of non-atopic asthma is likely in studies that included young children, in whom transient wheeze (often non-atopic) is common and 'true asthma' is difficult to diagnose. Thus, longitudinal studies are needed to fully characterise the relative importance of diverse asthma phenotypes in Latin America. Such studies, including biomarkers often lacking in previous literature, would allow better characterisation of risk factors for asthma in this region.

Because of the profound diversity of Latin Americans, genetic and epidemiological studies should include large subgroups that are defined with regard to place of birth, area of residence, migration history and racial ancestry. Given recent conflicts leading to forced displacement in several Latin American countries, the region offers a unique opportunity to examine the impact of these factors (and resulting stress) on asthma. Likewise, factors that may affect asthma and are common in certain Latin American countries deserve to be studied, including urbanisation, parasitic infections and biomass fuels. Along with these exposures, other emerging problems deserve attention, including diet and obesity.

Some problems may be unique to particular nations, but most Latin American countries share barriers to asthma management. Thus, concerted public health and research efforts could have a major impact at a regional level. Such efforts should include vigorous campaign to curtail and eliminate tobacco use, nationwide campaigns on asthma (directed at patients and healthcare providers), broadening access to care and clinical trials of relevant non-pharmacological interventions (eg, replacing biomass fuels with safe cooking techniques, violence and stress reduction, and weight loss).

\section{Author affiliations}

'Division of Pediatric Pulmonary Medicine, Allergy, and Immunology, Children's Hospital of Pittsburgh of UPMC, University of Pittsburgh, Pittsburgh, Pennsylvania, USA

${ }^{2}$ Fundación Hospital Universitario Metropolitano, Laboratorio de Alergia e Inmunología, Universidad Metropolitana, Barranquilla, Barranquilla, Colombia ${ }^{3}$ Division of Allergy and Immunology, Servicio de Alergia e Inmunología Clínica, Hospital Aeronáutico Central, Buenos Aires, Argentina

${ }^{4}$ Escola Paulista de Medicina, São Paulo, Brazil

${ }^{5}$ Laboratorio de Investigaciones FEPIS, Quinindé, Esmeraldas, Ecuador

${ }^{6}$ Institute of Infection and Immunity, St George's University of London, London, UK 
${ }^{7}$ Hospital Nacional de Niños, San José, Costa Rica

${ }^{8}$ Departments of Pediatrics and Public Health, School of Medicine, Pontificia Universidad Católica de Chile, Santiago, Chile

Contributors EF, MG, JAC-R and JCC contributed to the study concept, literature search, data collection and manuscript writing. AC, AY, DS, MS-Q, LA and PC contributed to the literature search and manuscript writing.

Funding This work was supported by grants HD052892, HL079966, HL073373 and HL117191 from the US National Institute of Health, and by the Heinz Endowments. Neither funding agency had any role in the preparation of this manuscript.

Competing interests None declared.

Provenance and peer review Not commissioned; internally peer reviewed.

\section{REFERENCES}

1 (WHO) WHO. Asthma. Secondary Asthma November 2013 2014. http://www.who. int/mediacentre/factsheets/fs307/en/

2 Committee IS. Worldwide variation in prevalence of symptoms of asthma, allergic rhinoconjunctivitis, and atopic eczema: ISAAC. The International Study of Asthma and Allergies in Childhood (ISAAC) Steering Committee. Lancet 1998;351:1225-32

3 Asher Ml, Montefort S, Bjorksten B, et al. Worldwide time trends in the prevalence of symptoms of asthma, allergic rhinoconjunctivitis, and eczema in childhood: ISAAC Phases One and Three repeat multicountry cross-sectional surveys. Lancet 2006;368:733-43.

4 CDC. Asthma Surveillance Data. Secondary Asthma Surveillance Data September 2, 2014 2014. http://www.cdc.gov/asthma/asthmadata.htm

5 Mallol J, Sole D, Baeza-Bacab M, et al. Regional variation in asthma symptom prevalence in Latin American children. J Asthma 2010:47:644-50.

6 Cooper PJ, Rodrigues LC, Cruz AA, et al. Asthma in Latin America: a public heath challenge and research opportunity. Allergy 2009;64:5-17.

7 Rosser FJ, Forno E, Cooper PJ, et al. Asthma in Hispanics. An 8 years update. Am J Respir Crit Care Med 2014;189:1316-27.

8 Caban-Martinez AJ, Halder GE, Tellechea L, et al. Health status and behaviors among adults residing in rural Dominican Republic. Rural Remote Health 2012;12:1956.

9 Schei MA, Hessen JO, Smith KR, et al. Childhood asthma and indoor woodsmoke from cooking in Guatemala. J Expo Sci Environ Epidemiol 2004;14(Suppl 1): S110-17.

10 de la Vega Pazitková T, Pérez Martínez V, Castillo Iriarte L. Comportamiento clínico-epidemiológico del asma bronquial en menores de 15 años. Bronchial Asthma Clinical and epidemiological pattern in children younger 15 years. Rev Cubana Med Gen Integr 2010;26:253-66.

11 Dennis RJ, Caraballo L, Garcia E, et al. Prevalence of asthma and other allergic conditions in Colombia 2009-2010: a cross-sectional study. BMC Pulm Med 2012;12:17.

12 Garcia-Sancho C, Fernandez-Plata R, Martinez-Briseno D, et al[Adult asthma in Mexico City: a population-based study]. Salud Publica Mex 2012;54:425-32.

13 Sole D, Filho NA, Sarinho ES, et al. Prevalence of asthma and allergic diseases in adolescents: 9 years follow-up study (2003-2012). J Pediatr (Rio J) 2014:91:30-5.

14 Prietsch SO, Zhang L, Catharino AR, et al. Asthma mortality among Brazilian children up to 19 years old between 1980 and 2007. J Pediatr (Rio J) 2012:88:384-8.

15 Solis Soto MT, Patino A, Nowak D, et al. Prevalence of asthma, rhinitis and eczema symptoms in rural and urban school-aged children from Oropeza Province —Bolivia: a cross-sectional study. BMC Pulm Med 2014;14:40.

16 Rodriguez A, Vaca M, Oviedo G, et al. Urbanisation is associated with prevalence of childhood asthma in diverse, small rural communities in Ecuador. Thorax 2011:66:1043-50

17 Liao Y, Cooper RS, Cao G, et al. Mortality from coronary heart disease and cardiovascular disease among adult U.S. Hispanics: findings from the National Health Interview Survey (1986 to 1994). J Am Coll Cardiol 1997;30:1200-5.

18 Brehm JM, Acosta-Perez E, Klei L, et al. African ancestry and lung function in Puerto Rican children. J Allergy Clin Immunol 2012;129:1484-90.e6.

19 Chen W, Brehm JM, Boutaoui N, et al. Native American ancestry, lung function, and COPD in Costa Ricans. Chest 2014;145:704-10.

20 Moreno-Estrada A, Gignoux CR, Fernandez-Lopez JC, et al. Human genetics. The genetics of Mexico recapitulates Native American substructure and affects biomedical traits. Science 2014;344:1280-5.

$21 \mathrm{Li} \mathrm{H}$, Romieu I, Wu H, et al. Genetic polymorphisms in transforming growth factor beta-1 (TGFB1) and childhood asthma and atopy. Hum Genet 2007;121:529-38.

$22 \mathrm{Wu} \mathrm{H}$, Romieu I, Shi M, et al. Evaluation of candidate genes in a genome-wide association study of childhood asthma in Mexicans. J Allergy Clin Immunol 2010;125:321-7.e13.
23 Galanter JM, Gignoux CR, Torgerson DG, et al. Genome-wide association study and admixture mapping identify different asthma-associated loci in Latinos: the Genes-environments \& Admixture in Latino Americans study. J Allergy Clin Immunol 2014:134:295-305.

24 Hunninghake GM, Soto-Quirós ME, Avila L, et al. Polymorphisms in IL13, total IgE, eosinophilia, and asthma exacerbations in childhood. J Allergy Clin Immunol 2007;120:84-90.

25 Lima CS, Neri IA, Lourenco GJ, et al. Glutathione S-transferase mu 1 (GSTM1) and theta 1 (GSTT1) genetic polymorphisms and atopic asthma in children from Southeastern Brazil. Genet Mol Biol 2010;33:438-41.

26 Jimenez-Morales S, Martinez-Aguilar N, Gamboa-Becerra R, et al. Polymorphisms in metalloproteinase-9 are associated with the risk for asthma in Mexican pediatric patients. Hum Immunol 2013;74:998-1002.

27 Isaza C, Sepulveda-Arias JC, Agudelo BI, et al. beta(2) -adrenoreceptor polymorphisms in asthmatic and non-asthmatic schoolchildren from Colombia and their relationship to treatment response. Pediatr Pulmonol 2012;47:848-55.

28 Giubergia V, Gravina L, Castanos C, et al. Influence of beta(2)-adrenergic receptor polymorphisms on asthma exacerbation in children with severe asthma regularly receiving salmeterol. Ann Allergy Asthma Immunol 2013;110:156-60.

29 Hunninghake GM, Soto-Quiros ME, Avila L, et al. TSLP polymorphisms are associated with asthma in a sex-specific fashion. Allergy 2010;65:1566-75.

30 Hunninghake GM, Cho MH, Tesfaigzi Y, et al. MMP12, lung function, and COPD in high-risk populations. N Engl J Med 2009;361:2599-608.

31 Torgerson DG, Ampleford EJ, Chiu GY, et al. Meta-analysis of genome-wide association studies of asthma in ethnically diverse North American populations. Nat Genet 2011:43:887-92.

32 Hancock DB, Romieu I, Shi M, et al. Genome-wide association study implicates chromosome 9q21.31 as a susceptibility locus for asthma in Mexican children. PLoS Genet 2009;5:e1000623.

33 Myers RA, Scott NM, Gauderman WJ, et al. Genome-wide interaction studies reveal sex-specific asthma risk alleles. Hum Mol Genet 2014;23:5251-9.

34 Pino-Yanes M, Gignoux CR, Galanter JM, et al. Genome-wide association study and admixture mapping reveal new loci associated with total IgE levels in Latinos. J Allergy Clin Immunol 2015;135:1502-10.

35 Hunninghake GM, Soto-Quiros ME, Lasky-Su J, et al. Dust mite exposure modifies the effect of functional IL10 polymorphisms on allergy and asthma exacerbations. J Allergy Clin Immunol 2008;122:93-8, 98.e1-5.

36 Figueiredo CA, Barreto ML, Alcantara-Neves NM, et al. Coassociations between IL10 polymorphisms, IL-10 production, helminth infection, and asthma/wheeze in an urban tropical population in Brazil. J Allergy Clin Immunol 2013;131:1683-90.

37 Moreno-Macias H, Dockery DW, Schwartz J, et al. Ozone exposure, vitamin C intake, and genetic susceptibility of asthmatic children in Mexico City: a cohort study. Respir Res 2013;14:14.

38 Chen W, Boutaoui N, Brehm JM, et al. ADCYAP1R1 and Asthma in Puerto Rican Children. Am J Respir Crit Care Med 2013;187:584-8.

39 Menezes AM, Perez-Padilla R, Jardim JR, et al. Chronic obstructive pulmonary disease in five Latin American cities (the PLATINO study): a prevalence study. Lancet 2005:366:1875-81.

40 Chong Neto HJ, Rosario NA, Grupo EC. Risk factors for wheezing in the first year of life. J Pediatr (Rio J) 2008;84:495-502.

41 Garcia-Marcos L, Mallol J, Sole D, et al. International study of wheezing in infants: risk factors in affluent and non-affluent countries during the first year of life. Pediatr Allergy Immunol 2010;21:878-88.

42 Rosas-Salazar C, Forno E, Brehm JM, et al. Breastfeeding duration and asthma in Puerto Rican children. Pediatr Pulmonol 2015;50:527-34.

43 Rosas-Salazar C, Ramratnam SK, Brehm JM, et al. Prematurity, atopy, and childhood asthma in Puerto Ricans. J Allergy Clin Immunol 2014;133:357-62.

44 Brehm JM, Celedon JC, Soto-Quiros ME, et al. Serum vitamin D levels and markers of severity of childhood asthma in Costa Rica. Am I Respir Crit Care Med 2009;179:765-71.

45 Brehm JM, Acosta-Perez E, Klei L, et al. Vitamin D insufficiency and severe asthma exacerbations in Puerto Rican children. Am J Respir Crit Care Med 2012;186:140-6.

46 Checkley W, Robinson CL, Baumann LM, et al. 25-hydroxy vitamin D levels are associated with childhood asthma in a population-based study in Peru. Clin Exp Allergy 2014;45:273-82.

47 Gutierrez-Delgado RI, Barraza-Villarreal A, Escamilla-Nunez MC, et al[Food consumption and asthma in school children in Cuernavaca, Morelos, Mexico]. Salud Publica Mex 2009;51:202-11.

48 de Cassia Ribeiro-Silva R, Fiaccone RL, Barreto ML, et al. The prevalence of wheezing and its association with serum zinc concentration in children and adolescents in Brazil. J Trace Elem Med Biol 2014;28:293-7.

49 Romieu I, Barraza-Villarreal A, Escamilla-Nunez C, et al. Dietary intake, lung function and airway inflammation in Mexico City school children exposed to air pollutants. Respir Res 2009;10:122.

50 Imhoff-Kunsch B, Stein AD, Martorell R, et al. Prenatal docosahexaenoic acid supplementation and infant morbidity: randomized controlled trial. Pediatrics 2011;128:e505-12. 
51 Rivera JA, de Cossio TG, Pedraza LS, et al. Childhood and adolescent overweight and obesity in Latin America: a systematic review. Lancet Diabetes Endocrinol 2014;2:321-32.

52 Noal RB, Menezes AM, Macedo SE, et al. Is obesity a risk factor for wheezing among adolescents? A prospective study in southern Brazil. J Adolesc Health 2012;51(6 Suppl):S38-45.

53 Forno E, Acosta-Perez E, Brehm JM, et al. Obesity and adiposity indicators, asthma, and atopy in Puerto Rican children. J Allergy Clin Immunol 2014;133:1308-14, 14.e1-5.

54 Barros LL, Souza-Machado A, Correa LB, et al. Obesity and poor asthma control in patients with severe asthma. J Asthma 2011;48:171-6.

55 Rojas-Dotor S, Segura-Méndez NH, Miyagui-Namikawa K, et al. Expression of resistin, CXCR3, IP-10, CCR5 and MIP-1? in obese patients with different severity of asthma. Biol Res 2013;46:13-20.

56 Del-Rio-Navarro BE, Castro-Rodriguez JA, Garibay Nieto N, et al. Higher metabolic syndrome in obese asthmatic compared to obese nonasthmatic adolescent males. J Asthma 2010;47:501-6.

57 Han A, Stewart DE. Maternal and fetal outcomes of intimate partner violence associated with pregnancy in the Latin American and Caribbean region. Int J Gynaecol Obstet 2014;124:6-11.

58 Lara MA, Navarrete L, Nieto L, et al. Prevalence and incidence of perinatal depression and depressive symptoms among Mexican women. J Affect Disord 2015; 175:18-24.

59 Barreto do Carmo MB, Neves Santos D, Alves Ferreira Amorim LD, et al. Minor psychiatric disorders in mothers and asthma in children. Soc Psychiatry Psychiatr Epidemiol 2009;44:416-20.

60 Vieira AA, Santoro IL, Dracoulakis S, et al. Anxiety and depression in asthma patients: impact on asthma control. J Bras Pneumol 2011;37:13-18.

61 Lange NE, Bunyavanich S, Silberg JL, et al. Parental psychosocial stress and asthma morbidity in Puerto Rican twins. J Allergy Clin Immunol

2011;127:734-40.e1-7.

62 Cohen RT, Canino GJ, Bird HR, et al. Violence, Abuse, and Asthma in Puerto Rican Children. Am J Respir Crit Care Med 2008;178:453-9.

63 Alves Gda C, Santos DN, Feitosa CA, et al. Community violence and childhood asthma prevalence in peripheral neighborhoods in Salvador, Bahia State, Brazil. Cad Saude Publica 2012;28:86-94.

64 Brehm J, Ramratnam SK, Tse SM, et al. Stress and bronchodilator response in children with asthma. Am J Respir Crit Care Med 2015;192:47-56.

65 Cooper PJ, Vaca M, Rodriguez A, et al. Hygiene, atopy and wheeze-eczema-rhinitis symptoms in schoolchildren from urban and rural Ecuador. Thorax 2014;69:232-9.

66 Alcantara-Neves NM, Veiga RV, Dattoli VC, et al. The effect of single and multiple infections on atopy and wheezing in children. J Allergy Clin Immunol 2012;129:359-67, 67.e1-3.

67 Rodrigues LC, Newcombe PJ, Cunha SS, et al. Early infection with Trichuris trichiura and allergen skin test reactivity in later childhood. Clin Exp Allergy 2008;38: 1769-77.

68 Moncayo AL, Vaca M, Oviedo G, et al. Effects of geohelminth infection and age on the associations between allergen-specific $\lg E$, skin test reactivity and wheeze: a case-control study. Clin Exp Allergy 2013;43:60-72.

69 Hunninghake GM, Soto-Quiros ME, Avila L, et al. Sensitization to Ascaris lumbricoides and severity of childhood asthma in Costa Rica. J Allergy Clin Immunol 2007;119:654-61.

70 Alcantara-Neves NM, Badaro SJ, dos Santos MC, et al. The presence of serum anti-Ascaris lumbricoides IgE antibodies and of Trichuris trichiura infection are risk factors for wheezing and/or atopy in preschool-aged Brazilian children. Respir Res 2010;11:114.

71 Bragagnoli G, Silva MT. Ascaris lumbricoides infection and parasite load are associated with asthma in children. J Infect Dev Ctries 2014;8:891-7.

72 Ponte EV, Rasella D, Souza-Machado C, et al. Reduced asthma morbidity in endemic areas for helminth infections: a longitudinal ecological study in Brazil. J Asthma 2014;51:1022-7.

73 Pereira MU, Sly PD, Pitrez PM, et al. Nonatopic asthma is associated with helminth infections and bronchiolitis in poor children. Eur Respir $J$ 2007;29:1154-60.

74 da Silva ER, Sly PD, de Pereira MU, et al. Intestinal helminth infestation is associated with increased bronchial responsiveness in children. Pediatr Pulmonol 2008;43:662-5.

75 López M, Bojanich MV, Jacobacci JM, et al. Toxocara canis y asma bronquial. Toxocara canis and bronchial asthma. Medicina 2010;70:75-8.

76 Moncayo AL, Vaca M, Oviedo $G$, et al. Risk factors for atopic and non-atopic asthma in a rural area of Ecuador. Thorax 2010;65:409-16.

77 Endara P, Vaca M, Chico ME, et al. Long-term periodic anthelmintic treatments are associated with increased allergen skin reactivity. Clin Exp Allergy 2010;40:1669-77.

78 Muino A, Menezes AM, Reichert FF, et al. [Wheezing phenotypes from birth to adolescence: a cohort study in Pelotas, Brazil, 1993-2004]. J Bras Pneumol 2008;34:347-55.
79 Dela Bianca A, Wandalsen G, Mallol J, et al. Risk factors for wheezing disorders in infants in the first year of life living in Sao Paulo, Brazil. J Trop Pediatr 2012;58:501-4.

80 Moraes LS, Takano OA, Mallol J, et al. Risk factors associated with wheezing in infants. J Pediatr (Rio J) 2013;89:559-66.

81 Hunninghake GM, Weiss ST, Celedon JC. Asthma in Hispanics. Am J Respir Crit Care Med 2006;173:143-63.

82 Herrera $A B$, Rodriguez LA, Niederbacher J. [Biological pollution and its relationship with respiratory symptoms indicative of asthma, Bucaramanga, Colombia]. Biomedica 2011;31:357-71.

83 Ly NP, Soto-Quiros ME, Avila L, et al. Paternal asthma, mold exposure, and increased airway responsiveness among children with asthma in costa rica. Chest 2008:133:107-14.

84 Blatter J, Forno E, Brehm J, et al. Fungal exposure, atopy, and asthma exacerbations in Puerto Rican children. Ann Am Thorac Soc 2014;11:925-32.

85 Forno E, Cloutier MM, Datta $\mathrm{S}$, et al. Mouse allergen, lung function, and atopy in puerto rican children. PLOS ONE 2012;7:e40383.

86 Jacobs TS, Forno E, Brehm JM, et al. Mouse allergen exposure and decreased risk of allergic rhinitis in school-aged children. Ann Allergy Asthma Immunol 2014;113:614-18.

87 Lynch SV, Wood RA, Boushey $\mathrm{H}$, et al. Effects of early-life exposure to allergens and bacteria on recurrent wheeze and atopy in urban children. J Allergy Clin Immunol 2014;134:593-601.e12.

88 Gomez M, Vollmer WM, Caceres ME, et al. Adolescent smokers are at greater risk for current asthma and rhinitis. Int J Tuberc Lung Dis 2009;13:1023-8.

89 Mallol J, Castro-Rodriguez JA, Cortez E. Effects of active tobacco smoking on the prevalence of asthma-like symptoms in adolescents. Int I Chron Obstruct Pulmon Dis 2007;2:65-9.

90 Escamilla-Nunez MC, Barraza-Villarreal A, Hernandez-Cadena L, et al. Traffic-related air pollution and respiratory symptoms among asthmatic children, resident in Mexico City: the EVA cohort study. Respir Res 2008;9:74.

91 Castro HA, Cunha MF, Mendonca GA, et al. Effect of air pollution on lung function in schoolchildren in Rio de Janeiro, Brazil. Rev Saude Publica 2009;43:26-34.

92 Wichmann FA, Muller A, Busi LE, et al. Increased asthma and respiratory symptoms in children exposed to petrochemical pollution. J Allergy Clin Immunol 2009:123:632-8.

93 Rosser F, Brehm JM, Forno E, et al. Proximity to a major road, vitamin d insufficiency, and severe asthma exacerbations in puerto rican children. Am J Respir Crit Care Med 2014;190:1190-3.

94 Romieu I, Riojas-Rodriguez H, Marron-Mares AT, et al. Improved biomass stove intervention in rural Mexico: impact on the respiratory health of women. $\mathrm{Am} \mathrm{J}$ Respir Crit Care Med 2009;180:649-56.

95 Wong GW, Brunekreef B, Ellwood P, et al. Cooking fuels and prevalence of asthma: a global analysis of phase three of the International Study of Asthma and Allergies in Childhood (ISAAC). Lancet Respir Med 2013;1:386-94.

96 Soto-Martinez M, Avila L, Soto N, et al. Trends in hospitalizations and mortality from asthma in Costa Rica over a 12- to 15 years period. J Allergy Clin Immunol 2014;2:85-90.

97 Neffen H, Baena-Cagnani C, Passalacqua G, et al. Asthma mortality, inhaled steroids, and changing asthma therapy in Argentina (1990-1999). Respir Med 2006;100:1431-5.

98 Fernández Rodríguez M, Orejón de Luna G. La ley antitabaco en espacios públicos se relaciona con la disminución de ingresos por asma infantil. The smoking ban in public places is related to the decrease in child asthma admissions. Rev Pediatr Aten Primaria 2013;15:371-4.

99 de la Vega Pazitková T, Pérez Martínez V, Bezos Martínez L. Relación entre la severidad de las manifestaciones de asma bronquial y el cumplimiento del tratamiento intercrisis. Relation between the severity of bronchial asthma manifestations and the fulfilment of the inter-crisis treatment. Rev Cubana Med Gen Integr 2011;27:294-306.

100 Vargas 0, Martinez J, Ibanez $M$, et al. The use of metered-dose inhalers in hospital environments. J Aerosol Med 2013;26:287-96.

101 Dalcin Pde T, Grutcki DM, Laporte PP, et al. Impact of a short-term educational intervention on adherence to asthma treatment and on asthma control. J Bras Pneumol 2011;37:19-27.

102 Henríquez MT, Ceruti DE. Educación en niños asmáticos controlados en hospital Roberto del Río: Impacto en conocimientos, adherencia y control de la enfermedad. Education in asthmatic children controlled at Roberto del Rio Hospital: Impact on knowledge, adhesion and disease control. Rev Chil Enferm Respir 2013;29:70-4.

103 Rodriguez-Martinez CE, Sossa-Briceno MP, Castro-Rodriguez JA. Cost-utility analysis of the inhaled steroids available in a developing country for the management of pediatric patients with persistent asthma. J Asthma 2013;50:410-18.

104 Rely K, McQuire SE, Alexandre PK, et al. [Cost effectiveness of treatment with salmeterol/fluticasone compared to montelukast for the control of persistent asthma in children]. Value Health 2011;14(5 Suppl 1):S43-7. 
105 Neffen H, Gonzalez SN, Fritscher CC, et al. The burden of unscheduled health care for asthma in Latin America. I Investig Allergol Clin Immunol 2010;20:596-601.

106 Castro-Rodriguez JA, Molina RO, Caceres M, et al. Correlation between nitrites in induced sputum and asthma symptoms in asthmatic schoolchildren. Pediatr Pulmonol 2014;49:214-20.

107 Rodriguez-Martinez CE, Melo-Rojas A, Restrepo-Gualteros SM, et al. Validation of the Spanish version of the childhood asthma control test (CACT) in a population of Hispanic children. J Asthma 2014;51:855-62.

108 Rodriguez-Martinez CE, Nino G, Castro-Rodriguez JA. Validation of the Spanish version of the Test for Respiratory and Asthma Control in Kids (TRACK) in a population of Hispanic preschoolers. I Allergy Clin Immunol 2014;2:326-31.e3.
109 Cruz AA, Souza-Machado A, Franco R, et al. The impact of a program for control of asthma in a low-income setting. World Allergy Organ J 2010;3:167-74.

110 Franco R, Nascimento HF, Cruz AA, et al. The economic impact of severe asthma to low-income families. Allergy 2009;64:478-83

111 Bunyavanich S, Soto-Quiros ME, Avila L, et al. Risk factors for allergic rhinitis in Costa Rican children with asthma. Allergy 2010;65:256-63.

112 Jacobs TS, Forno E, Brehm JM, et al. Underdiagnosis of allergic rhinitis in underserved children. J Allergy Clin Immunol 2014;134:737-9.e6.

113 Bueso A, Figueroa M, Cousin L, et al. Poverty-associated risk factors for wheezing in the first year of life in Honduras and El Salvador. Allergol Immunopathol (Madr) 2010;38:203-12.

114 Barreto ML, Cunha SS, Fiaccone R, et al. Poverty, dirt, infections and non-atopic wheezing in children from a Brazilian urban center. Respir Res 2010;11:167. 